\title{
Analysis of Quality Leadership in Reviving Economies and Politics in Muslim Countries
}

\author{
Mahfuzur Rahman (Corresponding author) \\ Faculty of Business and Accountancy \\ University of Malaya, 50603 Kuala Lumpur, Malaysia
}

Tel: 60-132-227-095Ｅ-mail: mahfuzanam@gmail.com

\author{
Hasanul Banna \\ Faculty of Business and Accountancy \\ University of Malaya, 50603 Kuala Lumpur, Malaysia
}

Md. Arphan Ali \& Md. Saifur Rahman

Faculty of Economics and Administration

University Of Malaya Kuala Lumpur, Malaysia

Received: January 12, 2014 Accepted: January 27, 2013

doi:10.5296/ber.v4i1.4899 URL: http://dx.doi.org/10.5296/ber.v4i1.4899

\begin{abstract}
It has been observed that there is a crisis of quality leadership in Muslim world for decades. Erosion of moral values among leaders contributes to the instability and poor economic performance for many Muslim countries. This study investigates factors that contribute to the deterioration of quality leadership in Muslim world. The study also investigates the role of quality leadership for unifying the Muslim Ummah. Descriptive and analytical research methods have been applied in this study to analyze the interviews as well as prior studies. The findings indicate that lack of sufficient education, dishonesty, lack of knowledge and dedication for country's development, absence of trustworthiness and responsibility, lack of moral values and avoidance of teaching of Al-Qur'an and As-Sunnah are the main factors that cause the deterioration of quality leadership in Muslim world. The study also concludes that honest and responsible leadership can contribute significantly to the economic development, political stability, peace and harmony of the Muslim world. This study recommends possible
\end{abstract}


initiatives in order to produce quality leadership skills in society, government and NGOs citizens.

Keywords: Quality Leadership, Economic \& Political development, Challenges, Muslim World

\section{Introduction}

The importance of quality leadership is undeniable for the sustainable economic growth and political stability in a country. It is considered as a significant tool to revive the economic development of a country. According to Jones \& Olken (2005), leadership matters for economic growth as individual leaders play significant role in accelerating overall economic growth of a nation. In the same context, Jones (2009) further argued that leadership selection also has large impacts on the economic growth of a nation. The quality leadership is developed thorough education, honesty, responsibility, dedication and others. There is a strong relationship between education and quality leadership. Most of the developed countries are economically strong and financially solvent due to their powerful political leadership and perhaps because their leaders are highly educated. On the other hand, most of the developing countries, particularly Muslim countries are far behind the developed nations in terms of economic growth and political stability, perhaps because their leaders are not highly educated. Prior studies suggest, countries that frequently experience dramatic reversal in growth, usually fail to carry forward their economic growth (Easterly, 1993 and Hausmann, 2005). Reversal of economic growth become a common phenomenon for many countries, particularly among the Muslim countries. Probably, this is because there are many political parties exist in developing countries like Bangladesh where mostly one party cannot be re-elected more than one time. As a result, when new party comes into power, they change the policy of previous rulings party which create barrier for economic growth. There are many examples that represent, changes in national leaders are systematically associated with changes in economic growth. For example, there is an evidence in the United States that incumbents are much more likely to be reelected during economic booms than during recessions (Fair \& Ray, 1978; Wolfers, 2002). Other research has found in cross-country settings that high growth rates inhibit coups (Londregan and Poole, 1990).

Leaders are important in every organization. A world without leaders is like a ship without lighthouse. Anyone can be leader by possessing strong leadership qualities. Everyone can be leaders by leading our inner self and leading others by example. But above all that a good or quality leadership depend on the qualification of a leader possess. The Islamic model of leadership emphasizes khuluq or behaving ethically towards all. It has been unanimously agreed upon Muslims and non-Muslims. Firmly grounded by the faith in God and mindful of the role as a trustee, as expected to be just, behave righteously, strive towards self-improvement and never breaks his/her word. The leader needs to consult with others, especially in areas where he/she is not competent. A leader is expected to bear adversity patiently and remain forever humble. Such exemplary Muslim leaders are rare. A Muslim leader should be humble and must never let his/her ego get the better of him/her. Umar (ra), the second Caliph, lived in a simple house. He had no bodyguards for his personal security, 
and walked in the streets of Madinah without any escort. Ali (ra), in his letter to Malik Al-Ashtar an-Nukhai, strongly encourages him to remain humble in his new position as Governor of Egypt and explained to him why pride and arrogance are to be avoided:

Never say to yourself, 'I am their Lord, their ruler, and I must be obeyed submissively and humbly.' Such a thought will unbalance your mind, will make you vain and arrogant, will weaken your faith in religion and will make you seek the support of any power other than God's.

The following story demonstrates how the Prophet (saw) exhibited patience and humility when a ban was imposed on the Muslims by others:

When we complained to God's Messenger (saw) of hunger and raised our clothes to show we were each carrying a stone over the belly, God's Messenger (saw) raised his clothes and showed that he had two stones on his belly.

This paper focuses on causes of the deterioration of quality leadership and its impact on country's economy and political development. Quality leadership is chosen because it is the key factor of a country to accelerate its economic development. No matter how the other sector of the economy grow if leaders are corrupted then it would create a barrier for the economic growth of country in the long run. The findings of our study specify some factors such as lack of sufficient education, honesty, lack of knowledge and dedication for country's development, absence of trustworthiness and responsibility, lack of moral values and avoidance of teaching of Al-Qur'an and As-Sunnah are the main factors that cause the deterioration of quality leadership in Muslim world. The study also concludes that honest and responsible leadership can contribute significantly to the economic development, political stability, peace and harmony of the Muslim world. The analysis also shows that lack of unity among the Muslim countries' leaders became barrier for unifying the Muslim Ummah.

The rest of this paper is organized as follows: An in-depth literature is discussed in section two following the research method in section three. Section 4 analyses the interviews to find out causes of deterioration of quality leadership and its impact on country's economic and political development. Section 5 provides several recommendations to produce the quality leadership, while the concluding remarks are presented in section-6.

\section{A Review of the Literature}

\subsection{Quality Leadership}

Quality leadership can be simply defined as focusing on people, social responsibility and quality of work. Feigenbaum (2007) stated that "quality today has become the foundation for constant management innovation and leadership" (p. 38). It is an intricate process as the persons in power influence their followers, civil society and wider public to accomplish societal goals. Perhaps the leadership style that most relates to quality leadership is the transformational leadership which "searches for ways to help motivate followers by satisfying high order needs and fully engaging them in the process of the work." (Horner, 1997, p. 275) .The essence of quality leadership is an undeniable fact for economic 
development. It is considered as one of the significant tools for accelerating economic growth of a country. For example, the economic success of East Asia is largely attributable to the adoption of developmentalism, i.e., the ideology that places highest priority on economic development (Watanabe, 1995). On the other hand, World Bank experts Kaufmann et al. (2002) have studied the association between governance and growth in developing countries. They identified voice and accountability, political stability, government's effectiveness, regulatory quality, rule of law and control of corruption as the main indicators of good governance. They found strong correlation between quality of governance and level of growth in a majority of the countries studies. Political leadership does influence to a large extent to these indicators of governance. The most imperative mechanism of quality leadership choose suitable policies and programmes, implementing them effectively and by reviving the required institutions for stepping up the rate of development.

\subsection{Quality Leadership and Edification}

There is a famous saying that Education is a Backbone of a nation. It is considered a shine light for society as well as nation as whole. As Leu \& Price-Rom (2006) have suggested: 'Educational quality in developing countries has become a topic of intense interest, primarily because of countries' efforts to maintain quality...in the context of quantitative expansion of educational provision... Whether explicit or implicit, a vision of educational quality is always embedded within countries' policies and programs' (p. 2). Beside that education is a lifelong process beginning at birth. Humans have a creative force which should be nurtured and allowed to grow in a fertile environment whether at home or at school. Similarly, Oduro \& MacBeath (2003), in talking of school leadership research, argue that 'much of this work is premised on competences or individual qualities of leaders which, it is assumed travel not only across institutional boundaries but also traverse national and cultural borders' ( $\mathrm{p}$. 441) .In addition to that education should be an ongoing preparation for life and with a goal for achieving the greater good. The detailed study of school leaders within (Brown \& Conrad, 2007) indicates a thoughtful avenue for future research explorations. This study examined 'principals' and other senior educational leaders' perspectives on school leadership and highlights approaches adopted by principals as they attempted to effectively meet the learning needs of students in a system characterized by an overly centralized bureaucracy in a time of continuous educational reform'. From the empirical evidence we can find that most of the developing countries leaders are not highly qualified. This might be due to the tradition of inherited power. This is really very common among the Muslim countries. As a result, most of the leaders become corrupted which undermines economic growth of a country. The fruits of an economic growth are concentrated only in the hands of few people.

\subsection{Quality Leadership and Inherited Leadership}

Inherited leadership refers to the leadership that passes among the family members. To some extent some leadership can be obtained by using money. Baldrige defines a Leadership System as an effective leadership system includes mechanisms for the leaders to conduct self-examination, receive feedback and improve (Baldrige National Quality Program, 2003). Leaders from that background as mentioned above try to prepare their sons or daughters to 
become leaders to accomplish something. This is common in traditional societies and this type of leadership is very obvious in many countries particularly in the Muslims countries. However, this leadership whether it is blessed or cursed is also currently debated in the many countries. But it is not common to traditional societies. It is also practiced in most of developed and stable democracies like the USA where Bush family has shown the characteristics of dynastic leadership. There are also many other example like in India, Rajiv Gandhi succeeded her slain mother; in Indonesia Meghawati Sukarnoputri became president partly because of her father's name; in Pakistan, Benezir Bhuttu; and in Bangladesh, shekh Hasina, the daughters of Shekh Mujib, and Khaled Zia, wife of President Zia (ex-political leaders) succeeded them on sympathy wave (G. Thimmaiah,n.a.). Now, the big question is whether they are able to uphold the inherited leadership or not to accumulate the economic growth of a country. According to Kirkpatrick and Locke (1996), the study of leader traits has a long and controversial history. While research shows that the possession of certain traits alone does not guarantee leadership success, there is evidence that effective leaders are different from other people in certain key respects.

\subsection{Quality Leadership and Situational Leadership}

There are so many unexpected political or economic incidents that may occur in a society or country which lead to bring out extraordinary leadership qualities in ordinary persons. The leadership of Mahatma Gandhi, Jawaharlal Nehru and Vallabhai Patel are brought out by the freedom movement (Thimmaiah \& Aziz, 1984). The researchers found that leaders emerged as a result of different situations. Therefore, the researchers assumed that leadership qualities were developed depending on the situation. However, there are people who believe that there are different styles of leadership which changes the situation. There are three basic things in a situational leadership; the foremost thing is that the relationship between the followers and the leader must be healthy. The followers must like the leader and support him/her in his goals. The second thing is that the task which is to be accomplished must be known, and the leader should set the goals as per the task to be done. Along with the tasks to be accomplished, the methods and standards to accomplish the task must also be specified in details, as this will make an impact on the followers. The third thing that is important is that the organization must confer the responsibilities of the task upon the leader, as this will strengthen the position of the leader.

\subsection{Leadership in Islam}

Muslims behave as leader and/or as follower depending on the Word of God as revealed in their holy book, the Qur'an. The Prophet Muhammad (saw) has emphasized a second major role of the Muslim leader: to protect his community against tyranny and oppression, to encourage God-consciousness and taqwa, and to promote justice. A commander (of the Muslims) is a shield for them. Whether as servant or as guardian, a Muslim leader may make use of certain bases of power to be effective. Islam recognizes the existence of power, but suggests etiquette for its use. They believe that the Prophet of Islam, Muhammad (saw), has modeled the way for Muslim leaders and followers for all times. This belief is supported when God says the following about Muhammad (saw): 
And you stand an exalted standard of character.

Muhammad's (saw) example, then, is what both Muslim leaders and followers seek to emulate. According to the Prophet Muhammad (saw), leadership in Islam is not reserved for small elite. Rather, depending upon the situation, every person is the "shepherd" of a flock, and occupies a position of leadership. Muhammad (saw) is reported to have said:

Each of you is a guardian, and each of you will be asked about his subjects.

In most circumstances in life, Muslims are urged to appoint a leader and follow him. According to the Prophet Muhammad (saw), Muslims must appoint a leader during a trip, select a leader to lead the prayer, and choose a leader for other group activities. Leadership, then, can be depicted as a process by which the leader seeks the voluntary participation of followers in an effort to reach certain objectives. This definition suggests that leadership is essentially a process whereby the leader guides willing followers. At all times, a leader must remember that he cannot compel others to do things against their will. According to Islam, the two primary roles of a leader are those of servant-leader and guardian- leader. First, the leader is the servant of his followers (sayyid al qawn khadimuhum). He is to seek their welfare and guide them towards good. The idea of a leader as a servant has been part of Islam since its beginning, and has only recently been developed by Robert Greenleaf: The servant-leader is servant first. It begins with the natural feeling that one wants to serve, to serve first. The best test, and the most difficult to administer, is: Do those serve grow as persons?

\section{Research Method}

This study uses qualitative research method to generate high quality data to fulfill our research objectives. This research selects 150 respondents from various part of the Muslim world using online interview. We have chosen various types of respondents to represent all classes of people who help us in explaining the causes of the deterioration of quality leadership. Over the years, number of leaders are increasing while number of good leaders are decreasing. In addition, normal people are the one who suffer the consequences of electing the unqualified leaders. Therefore it is very important for us to understand ordinary people views regarding significance of quality leadership to revive the Muslim countries' economy and politics, in order to implement appropriate solutions. To understand the causes of the deterioration of quality leadership online interview were conducted which helped to investigate the factors of the deterioration of quality leadership. However, the interviews were analyzed to find a pattern of the factors that were divided into 6 groups. Each group represents number of interviewees who have the same opinions regarding the causes of the deterioration of quality leadership and significance of quality leadership to revive the Muslim countries' economy and politics. A set of interview questions ware sent randomly among the various age group people to know their opinion. The responses were analyzed using content analysis method (qualitative method). Then, the results of content analysis were then coded into several categories. To make sure that the interviewees are the suitable target group to know about quality leadership, they were first asked how often they read newspaper and do they have in-depth idea about quality leadership. The sample included 60 per cent male and 
40 per cent female.

\section{Findings and Analysis}

Based on online interviews, in this section, we present several group of interviewees' opinions regarding causes of the deterioration of quality leadership and significance of quality leadership to revive the Muslim countries' economy and politics. Subsequently, the causes of the deterioration of quality leadership can be identified and from there on, several recommendations can be suggested to produce qualified leaders among the citizens.

\subsection{Interview Group 1}

This group believes that education is the most important tool whose lacking causes in producing unqualified leaders in the most of the country, particularly among Muslim countries. In many instances, leaders are not having necessary education. This results in tendency of being elected unqualified leaders. For example, the possibility of contribution in economic and social development by a person who never goes to school is less than who has basic education. If the candidate is educated he should have the good and better ideas to develop a country. Most of the interviewees think that, there should be a minimum qualification to enter politics. The politicians are the ones who can act like a brain for the country. Even for basic jobs, the companies are checking if the candidate has knowledge and capabilities to perform his responsibilities. Therefore, it should be mandatory to should have knowledge and graduation in specific domain since that person will represent the country/state/constituency and in a position to plan, take reasonable and intelligent decisions. There are many leaders who have no proper educational background but still occupies powerful position. Education is certainly the backbone of anyone who is interested to serve the country and holds the most important position in running the government. Due to the lack of education, corruption is deep rooted in most of the system which stop development of the country. It's not that ones who are educated are not corrupted but still educational background helps one to speak against corruption. The multi party system is certainly a curse for the democracy which has helped in increasing corruption and inclusion of leader who do not have proper educational background. This group emphasized the importance of educational qualification to avoid the unqualified leaders for other reasons than what has been agreed upon. They believe that most of the Muslim countries are economically backward and politically unstable due to lack of quality leaders. They also mentioned that Muslim world's downturns are also caused by the unskilled leaders.

\subsection{Interview Group 2}

The second interview group believes that a leader must be honest. Although they have mentioned about necessity of basic educational qualification but they think that the main traits that a political leader should have is honesty to face challenging situations for the welfare of the society. They claim that most of the leaders mainly work for their own development rather than country's development. In addition, they also think that education play only $30 \%$ role in producing highly qualified leaders and rest $70 \%$ are contributed by sincerity, honesty, dedication towards the work, understanding the situations, facing the 
situations. These are very important qualities a leader should have. Furthermore, they think that, the people should be honest too to choose the right leader to rule the country. This group thinks that the cause of deterioration of quality leadership is dishonesty. Most of the leaders are running for power and to serve their personal interest. Due to lack of honesty they become bias in decision making. In addition, many of the leaders are highly qualified but still corrupted. They are facing more problems related to scams, black money-hoarding, illegal sexual relationship and many more. If the leader has ability to read, understand and have strong leadership qualities along with honesty it is more than enough. As a leader, one should not be greedy. Each and every politician must strive hard to be honest throughout his life.

\subsection{Interview Group 3}

A group of interviewees think that a true leader need not to be educated but should be honest, full of zeal and enthusiasm and willingness to serve in true spirit. For instance, Akbar, the greatest and powerful Muslim emperor was illiterate. So there is a difference between education and knowledge. A leader must have knowledge which can be possible without acquiring education. Since a leader represents the people so he/she should have the basic knowledge about the society and some good moral values to be able to do justice for everyone. There is a huge difference between the education and the knowledge or wisdom. As we see everywhere that all successful people are not necessarily good at their education. But they are doing better than others due to their in-depth knowledge. Similarly it's not important for the leaders to have a high education too but must possess ability to face the challenges with his/her knowledge. This group of people thinks that lack of knowledge among the leaders causes the poor performance among the Muslim countries economy.

\subsection{Interview Group 4}

This group thinks that most of the leaders in the Muslim worlds are not trustworthy which causes the existing problems. Most of the leaders, today, is concern about their source of income and not for development of country because they are not trustworthy. A leader must be very responsible for the country's development. Most of the Muslim countries' leaders are not very responsible and trustworthy which causes many several problem problems like poverty, political instability and others.

\subsection{Interview group 5}

This group of interviewees thinks that erosion of moral values among leaders is contributing to the instability and poor economic performance for many Muslim countries. They also think that lack of family education causes for unqualified leaders. Erosion of moral values among youth (future leader) is contributing to lack of discipline, poor performance in school, general lack of respect to authority, poor self-esteem and others. Many strategies have failed to effectively foster moral growth of youths in educational institutions, including use of literature, art, operationally defining good character, building a universal set of morals and values, and many others. This group believes that "Islamic education in family" can be a fundamental powerful institution to produce future leaders so called youth. They think the main reasons for unqualified leader are lack of Islamic education in family. They also believe 
that Islamic education can be a powerful tool for inspiring youth to work for their countries' economic and societal development.

\subsection{Interview Group 6}

This group of interviewees believes the deterioration of quality leadership in today's Muslim world is due to avoidance of Al-Qur'an and As-Sunnah. A leader with good knowledge about Al-Qur'an and As-Sunnah consider himself and all his possessions as belonging to God. He bows his ego, ideas, passions and thinking to God. A leader with a firm believe does not dodge responsibility for his actions, rather continuously emphasize good deeds. To reinforce this idea, the Qur'an emphasizes on believe in God several times. Most of the Muslim countries' leaders do not possess the characteristics mentioned by the Al-Qur'an and As-Sunnah. Therefore, these countries are not really benefited by them in economically and socially.

\subsection{Causes of Deterioration of Quality Leadership}

Based on the information of various interviews above, the causes of deterioration of quality leadership are: (i) lack of basic education, (ii) dishonesty, (iii) lack of knowledge and dedication for country's development, (iv) absence of trustworthiness and responsibility, (v) lack of moral values, and (vi) avoidance of Al-Qur'an and As-Sunnah. These weaknesses exist among leaders, particularly among the developing countries which became obstacle for their development. The following issues contribute to increases the possibility of having unqualified leaders in most of the country.

i. Lack of education: in the absence of basic education, leaders tend to use the power for other reasons than the original purpose that the power were given for.

ii. Dishonesty: lack of honesty is the main source of corruption for a country which creates barriers for the development of a country.

iii. Lack of knowledge and dedication: lack of knowledge which may not necessarily related with education and personal gains are also a source of problem for the countries development.

iv. Absence of trustworthiness and responsibility: irresponsible and lack of accountability of a leader causes political instability for the country. It also creates poverty and increases the gap between reach and poor.

v. Lack of moral values: since the moral values among the young generation (the future leaders) have reduces dramatically, therefore the quality leadership particularly among the Muslims countries are deteriorated.

vi. Avoidance of Al-Qur'an and As-Sunnah: avoidance of Al-Qur'an and As-Sunnah making the leaders dishonest, selfish and injustice which are the main for any country development. 


\section{Recommendations}

\subsection{Mandatory Basic Education}

To reduce the unqualified leaders, there should be a rule in maintaining a minimum level of academic qualification in order to hold a leading position. Since education enhances knowledge and knowledge is wisdom, educated politician can think smart and work more efficiently for the betterment of the country. Educated leaders are important for the prosperity of a country. They have the ability to think clearly and can face the problems of a country. Educated leaders know the meaning of word (Democracy) so they can make a Democratic country. Education cannot guarantee that an educated leader can do everything but a person administrating such a diversely populated country should have some reasonable educational background as education helps in developing attitudes and manner in life which helps a person( in this case a politician) to adapt to this fast changing world and serve the society in a more appropriate way. Education is certainly the backbone of anyone who is interested to serve the country and holds most of the major jobs of running the government. And because of lack in education corruption is deep rooted in most of the countries' political system. Some of the educated persons are corrupted as well but still ethical education helps to speak against corruption. The multi-party system is certainly a curse for the democracy which has helped in increasing corruption and inclusion of man who do not have proper educational background. It is not only that the politician should be educated but also the people should be educated. Then only the people can choose the right person to rule the country.

\subsection{Introduction of Islamic Family Education}

People generally learn the basic knowledge from their family. Now-a-day, in most of the Muslim countries even do not have Islamic family education. Most of the families even in Muslim countries produce unqualified and moral values less young generation. People become more materialistic and only focuses on the instant gain, therefore parents do not bother to teach moral values. Young generation is adopting wrong culture and habits in the name of modernization. As a result, young generations through the world are in danger compare to the couple of decades ago. Since today's young generation is the leaders for the future so it is very important to introduce Islamic family education to produce good leader. In Islam to serve God, a Muslim leader is to act in accordance with the injunctions of God and His Prophet (saw), and must develop a strong Islamic moral character. This moral character will be reflected by his increasingly strong belief in God as he progresses through 4 stages of spiritual development: Iman, Islam, Taqwa and Ihsan. Usually, a child become good if the family is good without some exceptions. And a family can only be good and happy if there are Islamic values. Therefore, introduction of Islamic family education contributes to produce morally good and skilled leaders.

\subsection{Mandatory Depth Knowledge about Al-Qur'an and As-Sunnah}

In order to reduce the unqualified leaders it is necessary to make a rule that if anyone one want to be leader he/she must possess in-depth knowledge about Al-Qur'an and As-Sunnah. Since Al-Qur'an and As-Sunnah give knowledge and wisdom. A leader with good knowledge 
about Al-Qur'an and As-Sunnah consider himself and all his possessions as belonging to God. Most of the Muslim countries leaders do even not possess the characteristics mentioned by the Al-Qur'an and As-Sunnah. Therefore, we must make sure that the leaders have adequate knowledge about Al-Qur'an and As-Sunnah which help to produce quality leadership.

\subsection{Leadership Training}

The training is very important to produce a quality leader. It can be done through camp, campaign, conferences and others. Current education system has less application of subjects where there is a very minimum opportunity of developing leadership skills. Therefore, proper Islamic leadership training can be a good source to produce quality leaders who have basic education with in-depth knowledge about Al-Qur'an and good family background.

\subsection{Establishment Islamic Institutions}

One of the major sources of quality leaders can be the Islamic institutions. These institutions provide both if Islamic knowledge and conventional knowledge. The former helps to produce morality and ethics of leaders and the later equip with modern knowledge to lead and develop the country by competing others countries of the world. In the recent world knowledge is the most powerful weapon to fight and survive. Therefore a leader must be knowledgeable to carry forward the country in which the Islamic institutions can play the key contributions.

\subsection{Improvement of Followers ' Characteristics}

Follower characteristics are also important factors in producing quality leadership. Just as in the case of their leader, the characteristics of Muslim followers affect their behavior. Therefore, the followers must possess good qualities which help to produce good leaders. Although some people think that if the leader is good then people would be good which is true but if most of the people are not good then how the good leaders would be elected, for instance in a demotic country. Therefore, a good follower is very important element to produce quality leader.

\section{Conclusion}

A leader is not only defined as a president, or, prime minister, or religious leaders rather this term represents many matters in leading. For example, every individual is a leader for himself or herself, a parent is the leader for their families, and a teacher is the leader for their students, an imam is the leader for certain community and others. All these leaders have their own role, obligation and responsibilities. If they fulfill their task honestly and perfectly, then the country will be developed and will prevail peace and harmony. A leader has difficult and broad responsibilities towards the people. Erosion of moral values among leaders in all over the world became a great concern among the people. Lack of basic education, honesty, knowledge and dedication for country's development, absence of trustworthiness and responsibility, lack of moral values, and avoidance of Al-Qur'an and As-Sunnah are the causes of deterioration of quality leadership.These weaknesses are existing among leaders, particularly among the developing countries leaders and its became obstacle for their development. The lack of unity among the Muslim countries leaders became the barrier for 
unifying the Muslim Ummah. Therefore, each individual, family, society, government, Islamic Institution and NGOs should contribute in producing quality leadership skills among the citizens.

\section{References}

Al-Buraey, M. (1985). Administrative Development: An Islamic Perspective. London, UK: KPI.

Blondel, J. (1987). Political leadership: towards a general analysis. London: Sage Publications.

Brown, L., \& Conrad, D. A. (2007). School leadership in Trinidad and Tobago: The challenge of context. Comparative Education Review, 51(2), 181-201. http://dx.doi.org/10.1086/512021

Butterfield, H. (1931). The Whig Interpretation of History. London: G. Bell and Sons. Computers

Easterly, W., Kremer, M., Pritchett, L., \& Summers, L. H. (1993). Good policy or good luck?. Journal of Monetary Economics, 32(3), 459-483. http://dx.doi.org/10.1016/0304-3932(93)90026-C

Fair, R. C. (1978). The effect of economic events on votes for president. The Review of Economics and Statistics, 60(2), 159-173. http://dx.doi.org/10.2307/1924969

Faqih, I. (1988). Glimpses of Islamic History. Delhi, India: Adam Publishers and Distributors. Feigenbaum, A.V. (2007). The international growth of quality. Quality Progress, 40(2), 36-40.

French Jr, J. R., \& Raven, B. (1959). The bases of social power.

Greenleaf, R. K. (1973). The servant as leader. Center for Applied Studies.

Hamilton, B. A. (2003). Assessment of Leadership Attitudes about the Baldrige National Quality Program. Malcolm Baldrige National Quality Program, National Institute of Standards and Technology, Gaithersburg, MD.

Hausmann, R., Pritchett, L., \& Rodrik, D. (2005). Growth accelerations. Journal of Economic Growth, 10(4), 303-329. http://dx.doi.org/10.1007/s10887-005-4712-0

Haykal, M. H. (1976). The Life of Muhammad (saw). Indianapolis: IN, American Trust Publications.

Hollander, E. P. (1978). Leadership Dynamics. New York: Free Press.

Horner, M. (1997). Leadership theory: past, present and future. Team Performance Management, 3(4), 270-287. http://dx.doi.org/10.1108/13527599710195402

ISEC. (2005). Karnataka Development Report, Bangalore.

Islamic Scholar Software. Mishkat Al-Masabih. (1996) South Africa: Johannesburg: Par Excellence.

Islamic Scholar Software. Sahih Bukhari. (1996) South Africa: Johannesburg: Par Excellence 
Computers.

Islamic Scholar Software. Sahih Muslim. (1996) South Africa: Johannesburg: Par Excellence Computers.

Jones, B. F. (2009). National leadership and economic growth. The New Palgrave Dictionary of Economics.

Jones, B. F., \& Olken, B. A. (2005). Do leaders matter? National leadership and growth since World War II. The Quarterly Journal of Economics, 120(3), 835-864.

Kaufmann, D., Kraay, A., \& Lobaton, P. Z. (2002). Governance matters II: updated indicators for 2000-01 (Vol. 2772). World Bank-free PDF.

Kirkpatrick, S. A., \& Locke, E. A. (1996). Direct and indirect effects of three core charismatic leadership components on performance and attitudes. Journal of Applied Psychology, 81(1), 36. http://dx.doi.org/10.1037/0021-9010.81.1.36

Leu, E., \& Price-Rom, A. (2006). Quality of education and teacher learning: A review of the literature. Washington, DC: USAID Educational Quality Improvement Project, 1.

Londregan, J. B., \& Poole, K. T. (1990). Poverty, the coup trap, and the seizure of executive power. World politics, 42(2), 151-183. http://dx.doi.org/10.2307/2010462

Muganda, A. (2004, May). Tanzania's Economic Reforms and Lessons Learned. In Scaling Up Poverty Reduction: A Global Learning Process and Conference. Shanghai.

Ngowi H. P. (2002). The Role of Foreign Direct Investments (FDIs) I Host Economies: A Focus on Tanzania. Unpublished, All But DissertationThesis. Norwegian School of Economics and Business Administration

Oduro, G. K., \& MacBeath, J. (2003). Traditions and tensions in leadership: the Ghanaian experience. Cambridge Journal of Education, 33(3), 441-455. http://dx.doi.org/10.1080/0305764032000122050

Randa, J. (1999). Economic Reform and the Stability of the Demand for Money in Tanzania. Journal of African Economies, 8(3), 307-344. http://dx.doi.org/10.1093/jae/8.3.307

Samoff J, Graham JD. (1975). Tanzania: Local Politics and the Structure of Power. Int. J. Afr. Hist. Stud. Book Review. 8(3), 483-483. http://dx.doi.org/10.2307/217168

Soanes, C. \& Stevenson, A. (2003). Eds. Oxford Dictionary of English Guruswamy.Social Power. Ann Arbor, Mich.: University of Michigan, 150-167.

Thimmaiah, G., \& Aziz, A. (1983). The political economy of land reforms. Ashish Publishing House.

Watanabe, T. (2004). I Prologue. Japanese Views on Economic Development: Diverse Paths to the Market, 186.

Wolfers, J. (2002). Are voters rational? Evidence from gubernatorial elections. Graduate 


\section{Macrothink}

School of Business, Stanford University.

\section{Copyright Disclaimer}

Copyright reserved by the author(s).

This article is an open-access article distributed under the terms and conditions of the Creative Commons Attribution license (http://creativecommons.org/licenses/by/3.0/). 